\title{
Steppe Eagle in the Kharkiv Region From Ukraine: Registration, Possible Causes of the Observed Phenomena
}

\section{СТЕПНОЙ ОРЁЛ В ХАРЬКОВСКОЙ ОБЛАСТИ УКРАИНЫ: ФАКТЫ НАХОДОК, ВОЗМОЖНЫЕ ПРИЧИНЫ НАБЛЮДАЕМОГО ЯВЛЕНИЯ}

\author{
Viter S. G. (National nature park "Gomilshansky Lisy", Kharkiv region, Ukraine) \\ Витер С.Г. (Национальный природный парк «Гомольшанские леса», Харьковская \\ область, Украина)
}

\author{
Контакт: \\ Станислав Витер \\ Национаиьный \\ природный парк \\ "Гомольшанские леса" \\ 61077, Украина, \\ Харьков, \\ пл. Свободы, 4 \\ elbasan-viter@mail.ru
}

Contact:
Stanislav Viter
Interdepartment
laboratory "Biodiversity
investigation
and conservation
development”
National Park
"Gomilshansky Lisy"
Svobody sq., 4
Kharkiv, Ukraine, 61077
elbasan-viter@mail.ru

Резюме

Степной орел (Aquila nipalensis) в Украине в настояшее время является редким залётным видом, последние Аостоверные случаи гнездования отмечены в заповеднике Аскания-Нова в 1970-х гг., а птицы на участках встречались в период Ао 1981 г. В Харьковской области Аостоверные встречи в гнездовой период отмечены в южных частях региона в конце XIX в. Наши исследования орнитосрауны Харьковщины проходили в 2003-2016 гг. За этот период нам стало известно о 5 регистрациях степного орла в 5 районах области. Из этих регистраций 2 относятся к периоду гнездования (вторая половина мая - средина июля), 1 - к периоду послегнездовых кочёвок (вторая половина июля - первая половина августа) и 2 - к периоду миграционных перемешений (март - средина мая, средина августа - октябрь).

Киючевые слова: хищные птицы, пернатые хищники, степной орёл, Aquila nipalensis, Украина, Харьковская область.

Поступияа в редакцию: 22.09.2016 г. Принята к публикации: 30.10.2016 г.

\section{Abstract}

The Steppe Eagle (Aquila nipalensis) is a very rare vagrant in Ukraine. It bred here in 1970s, and adults were recorded in summer on their nesting sites up until 1981. In the Kharkiv region (Eastern and N-E. Ukraine) the species was noted as breeding in the second half of 19 century. Our survey was carried out in 2003-2016. For this period, we have known about the 5 registrations of Steppe Eagles in 5 districts. Two of these registrations were made at the breeding season (second half of May - mid-July), one - at the period of post-nesting movements (the second half of July - the first half of August) and 2 - at the period of migration (March - middle of May, middle August - October).

Keywords: birds of prey, raptors, Steppe Eagle, Aquila nipalensis, Ukraine, Kharkiv region.

Received: 22/09/2016. Accepted: 30/10/2016.

DOI: $10.19074 / 1814-8654-2016-33-54-60$

\section{Введение}

Степной орёл (Aquila nipalensis) в Украине в настояшее время является редким залётным видом, последние достоверные случаи гнездования отмечены в заповеднике Аскания-Нова в 70-х гг. XX столетия, а птицы регулярно встречамись в период Ао 1981 г. (Червона книга України, 1994, 2009; Кошелев и Ар., 1991). В Харьковской области Аостоверные встречи в гнездовой период отмечены в южных частях региона в конце XIX столетия (Сомов, 1897). В более поздних работах фактически нет информации о встречах степного орла, будь то регистрации птиц в периоА миграций или гнездовой период.

\section{Методика}

Исследования гнездовой и зимней фауны хишных птиц (виАОвой состав, численность) проводили стандартными методами сплошного учёта и многократного картирования, а также маршрутными методами. Пройдено более 5000 пеших и автомо-

\section{Introductions}

The Steppe Eagle (Aquila nipalensis) is a very rare vagrant species in Ukraine. It bred here in 1970s, and birds were observed in summer on their nesting sites up until 1981. In the Kharkiv region (Eastern and N-E. Ukraine) this species was recorded as breeding in the second half of 19 century.

\section{Methods}

Research of breeding and wintering raptors aimed at the revision of species numbers and population status was performed with standard methods both total census and repeated mapping and transect accounts as well. The total length of pedestrian and vehicle routes across potential habitats of the Steppe Eagles in the central, northern, south-eastern, north-west and partly south-western, north-eastern and southern parts of the Kharkiv region was $5000 \mathrm{~km}$. Surveys conducted were aimed at the identification and monitor- 
бильных маршрутов (без учётов повторных прохождений одного маршрута) в биотопах, гАе потенциально могут быть встречены степные орлы, в центрамьной, северной, юго-восточной, северо-западной и, отчасти, юго-западной, северо-восточной и южной частях Харьковской области. Основную массу исследований проводили с целью выявления и мониторинга гнездовой популяции орла-могильника (Aquila heliaca) и Аругих гнездяшихся видов хишных птиц, а информацию о встречах степного орла собирали попутно. В период миграций (преимушественно осенних) с 2007 г. по 2016 г. проводили наблюдения на точках на возвышениях коренного берега Северского Аонца в Национаиьном природном парке "Гомольшанские леса". Наблюдениями охвачено около 1/3 всего времени осенних миграций хишных птиц.

Аля целей данной статьи собрана информация о поступлении подранков или больных крупных орлов в Харьковский зоологический парк, а также убитых или погибших птиц в Музей природы Харьковского национального университета за период с 1993 по 2016 гг. Эти сведения сушественно Аополняют информацию о встречах степного орла в Харьковской области, опубликованную ранее (Витер, 2013).

\section{Результаты и обсужиение}

Нами отмечено 5 встреч степного орла (рис. 1) в пределах административных границ Харьковской области. Регистра-

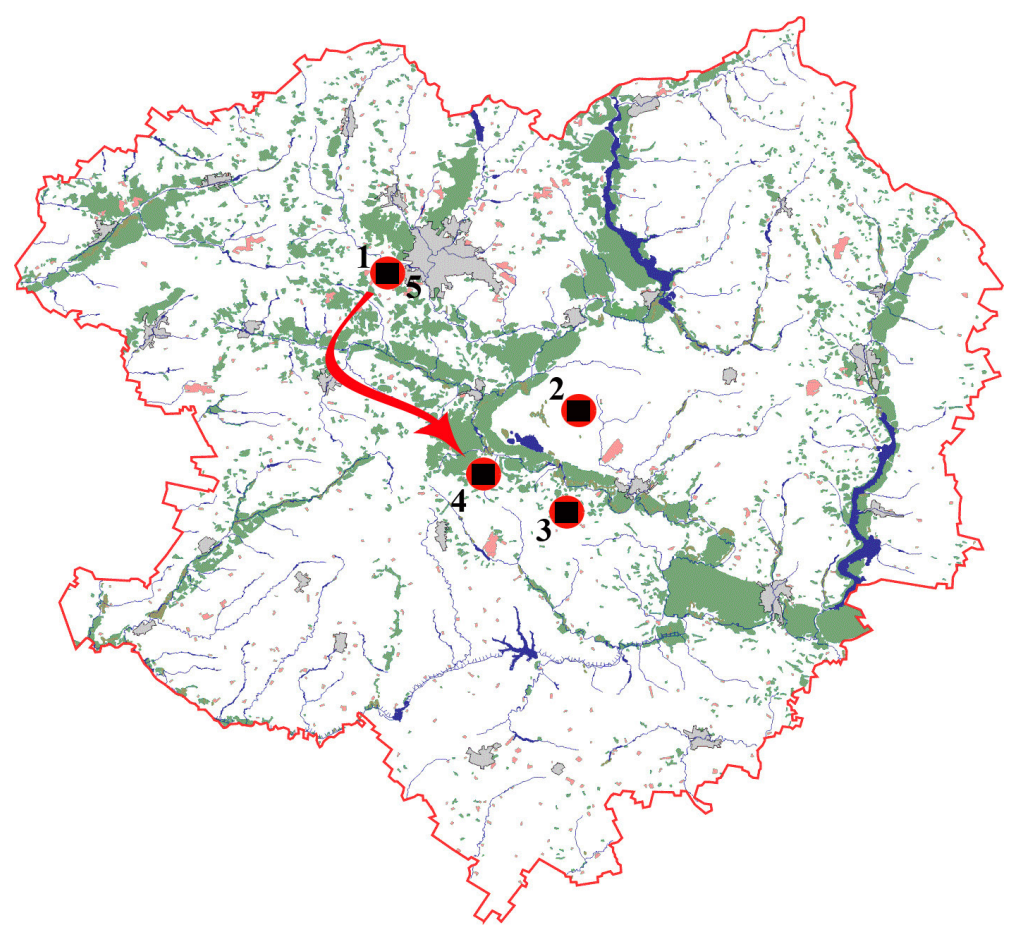

ing of the Eastern Imperial Eagle (Aquila heliaca) and other raptor species breeding in the region. The information about Steppe Eagle records was collected along the way. During migrations (mostly autumn) since 2007 to 2016 observations were made in the points on the elevations of the high right bank of the Siversky Donets river in the National Nature Park "Gomilshans'ky Lisy". Observations covered about $1 / 3$ of all time of autumn migration of raptors.

\section{Results and discussion}

Our surveys were carried out in 20032016. For this period, we have known about the 5 registrations of Steppe Eagles in 5 districts. Two of these registrations were made at the breeding season (second half of May - mid-July), one - at the period of post-nesting movements (the second half of July - the first half of August) and 2 - at the period of migration (March - middle of May, middle August - October). All the birds registered were observed in the following landscapes: 4 - in southern spurs of the Central Russian (East European) Upland, where encountered in steppe valleys, fields, fragmented oak forests), one - on a wide flat loess terrace of the Siversky Donets river valley (fig. 1). Preferred habitats are flat plains on river terraces, steppe depressions surrounded by fields with fragmented oak forests (fig. 2). Our study has shown the Steppe Eagle being the most vulnerable among the large eagle species.

Being the rarest large eagle species in Ukraine, the Steppe Eagle is a species, which falls into "trouble" more than other Eagles species proportionally (for its number): in the Kharkiv region one of 5 known records were the bird delivered to the Kharkiv Zoo (fig. 3). For example, there are only 4 such events with Eastern Imperial Eagles in the period from 1993 to 2016, but regional population of this species is esti-

Pис. 1. Геограсиия регистраций степного орла (Aquila nipalensis) в Харьковской области, Украина. Точки встреч птиц: 1 - 2003 г., 2 - 2011 г., 3 - 2015 г., 4 - 1 сентября 2016 г., 5 - 1 июня 2016 г. Стрелкой обозначено место возврата птицы в природу из точки 5.

Fig. 1. Steppe Eagle (Aquila nipalensis) registrations in the Kharkiv region, Ukraine. Observations: 1 - 2003, 2-2011, 3-2015, 4- 1 September 2016, 5 - 1 June 2016. Arrow denotes the site of the bird release in the wild in the point 5. 


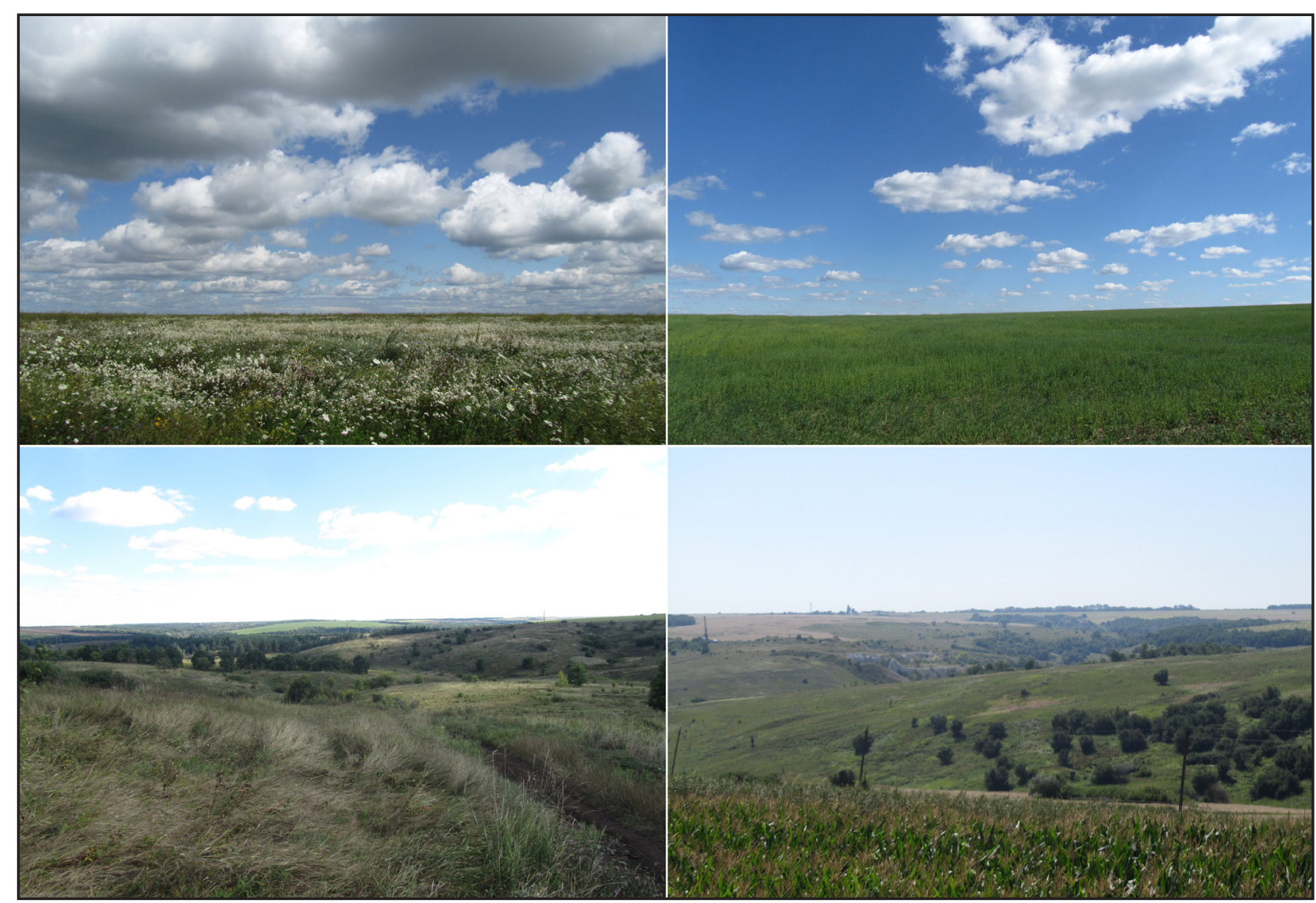

ции вида приходятся на северные и центральные районы, в ландшафтном плане тяготеют к южным отрогам Среднерусской (Восточноевропейской) возвышенности и широкой Аолины (террасы) Северского Аонца. Птицы встречены как в типично степных, так и лесостепных ландшастах (рис. 2). Ниже приведён список встреч птиц за периол с 2003 по 2016 годы.

1. 2003 год, июнь: взрослую птицу наблюдал начальник отлела содержкания хищных птиц Харьковского зоопарка В.И. Гук, в поле у съезла с окружной трассы на $\Delta$ рогу в сторону пос. Буды. Там же отмечена птица в 2016 году (см. ниже). Аругих видов крупных орлов и филина (Bubo bubo) на участке нет. Аандшаст представляет собой обширные поля с участками нагорных $\Delta y-$ брав и небольшими фрагментами луговых степей по крутым балкам. На стационаре есть птицеопасные АЭП (10 кВ).

2. 2011 гол, 26 апреля: 1 птицу (судя по особенностям окраски - орла возрастом 3 года) наблюдали в окрестностях с. Благодатное Змиевского района; орёл на небольшой высоте парил нах полями и залежами с участками степи на 5 террасе долины Северского Аонца, набрав высоту, полетел в северо-восточном направлении. Аия рельефа в Аанной местности
Рис. 2. Варианты ландшафтов, в которых отмечены степные орлы. Фото С. Витера.

Fig. 2. Different landscapes where Steppe Eagles were registered. Photos by S. Viter.

mated as about 120 adults and not less than 60 fledglings per year.

The nearest Steppe Eagle nesting sites are located in the Volgograd region and Kalmykia of the Russian Federation, where the population trend is negative as well (Karyakin, 2012). A pair in this population produces usually not more than a fledgling per successful nest. So, the nearest known populations are unlikely to produce a sufficient number of fledglings which are prone to nomad lifestyle. Frequent records of Steppe Eagles in recent years can testify to such a process: survival increase of juvenile and subadult (immature) birds, degradation in some population with followed by the immigration of the birds in search of better living conditions.

There is a low probability of the Steppe Eagle breeding over the next 10 years, but we hope that it will become a regular vagrant (now - rare irregular vagrant) and summering species in the Kharkiv region of Ukraine. 
характерно отсутствие пересечённости, почти не выраженный укион, наличие небольших степных "блюдец", заполняемых водой в периоды обильных летних осадков и, чаше, в период таяния снега. $\Delta$ ревесной растительности фрактически нет, мишь небольшая лесополоса по периферии полей. На стационаре проводят регулярные наблюдения и учёты, как в период миграций, так и в сезон гнездования. $\Delta$ и и после этой регистрации степных орлов зАесь не отмечами. На территории стационара стабильно (с 2007 года) гнездиться пара орАов-могильников, в некоторые годы отмечено 1-2 полувзрослых особи этого вида. Также установлено гнездование пары курганников (Buteo rufinus) и нерегулярное гнездование орла-карлика (Hieraaetus pennatus). На стационаре есть птицеопасные АЭП (10 кВ).

3. 2015 гол, 25 июля: 1 птицу в возрасте предположительно 5 лет наблюдаии в окрестностях с. Пятигорское Баиакиейского района. Птица парила нац полями, полетела в сторону колонии крапчатого суслика (Spermophilus suslicus) у с. Жовтневое. ия территории характерны выраженная пересечённость рельесра, начичие островных (байрачных) дубрав и остатков нагорных дубрав, обширные поля, широкие степные баики с разной интенсивностью выпаса, в том числе и полынные сбои. На территории стабильно обитает пара орлов-могильников (наблюдения провоАят с 2010 года). На этом же стационаре отмечено гнездование пары орлов-карликов и сушествует большая гнездовая группировка курганника (не менее 30 пар на 1000 км² обшей плошали). Наблюдаемый нами степной орёл не приближаися к большой сваике птицесабрики, гАе в это время кормились 7 чёрных коршунов (Milvus migrans) и пара орлов-могильников. На стаци-

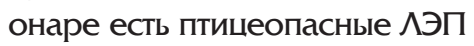
(10 кB).

Рис. 3. Степной орёл, Аоставленный в Харьковский зоопарк в июне 2016 года (возврашён в природу 10.09.2016). Фото С. Витера.

Fig. 3. Steppe Eagle which was brought to the Kharkiv Zoo in June 2016 (and was released in the wild on 10 September 2016). Photos by $S$. Viter.
4. 2016 год, 1 сентября: 1 птицу (предположительно, 5-летнего возраста) наблюдали в степной балке с редколесьями на границе Змиевского и Первомайского районов. Птица парила, улетела в южном направлении. На примыкаюших плакорах расположены обширные поля и залежи, есть широкие степные балки, некоторые с крутыми скионами, местами переходяшие в каньоны, с островками байрачных мубрав. На участке отмечено нерегулярное гнездование пары могильников, есть курганники и орлы-карлики. Наблюдения на стационаре в течение всех сезонов провоАят с 2006 года. На стационаре отсутству-

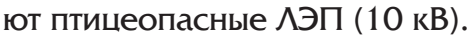

5. 2016 год, 1 июня: 1 птицу 3-летнего возраста (рис. 3) доставили в Харьковский зоопарк из окрестностей города Харькова (окрестности пос. Буды). По словам Аоставивших её местных жителей, орла "отняли в полях у стаи из 6 собак, с которыми птица мралась...". Более подробные обстоятельства этого события нам не известны. Есть предположение, что птица могла атаковать одну из мелких собак в

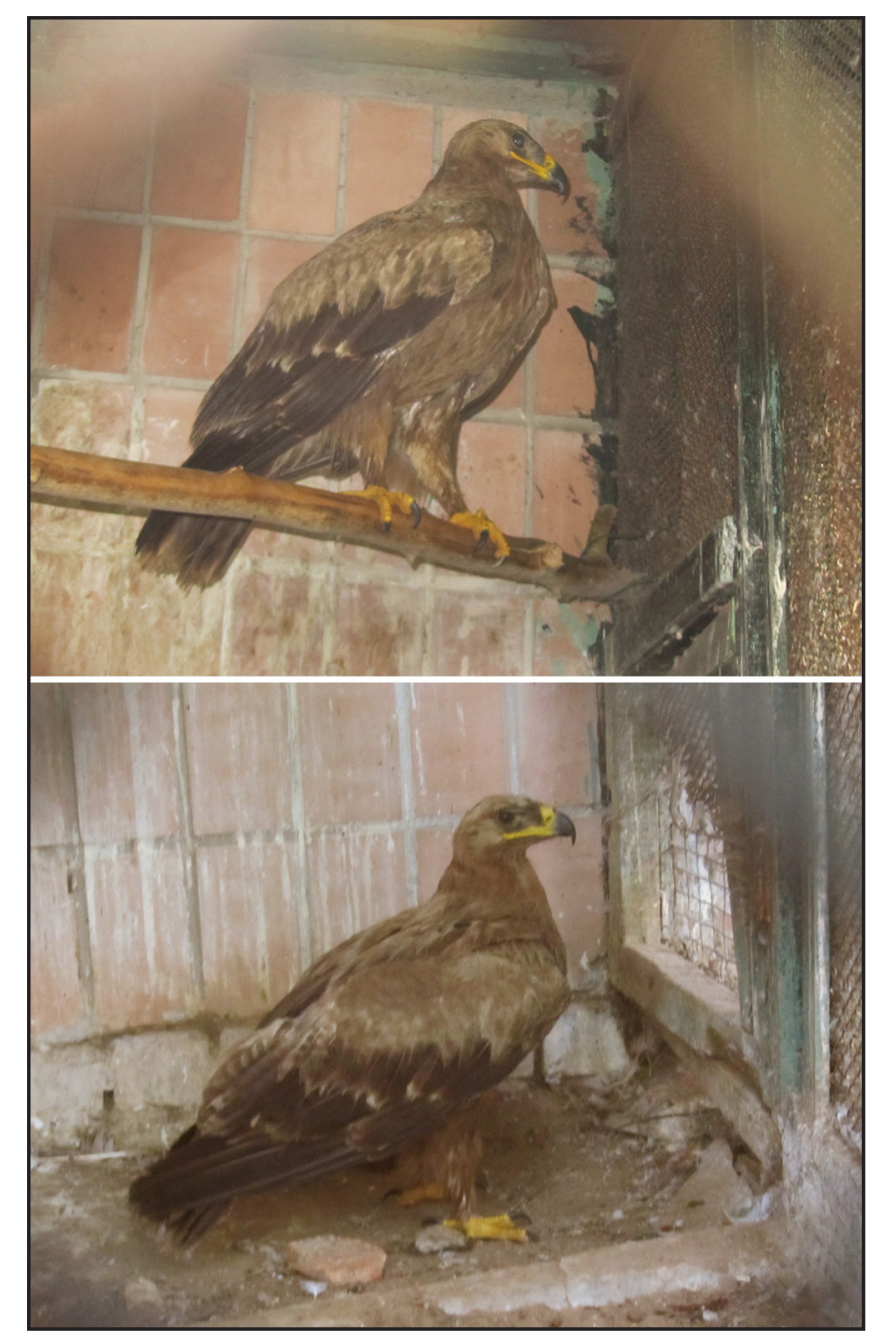


Кольцевание степного орла перед выпуском в природу.

Фото С. Витера.

The Steppe Eagle ringing before its releasing in the wild. Photo by $S$. Viter.

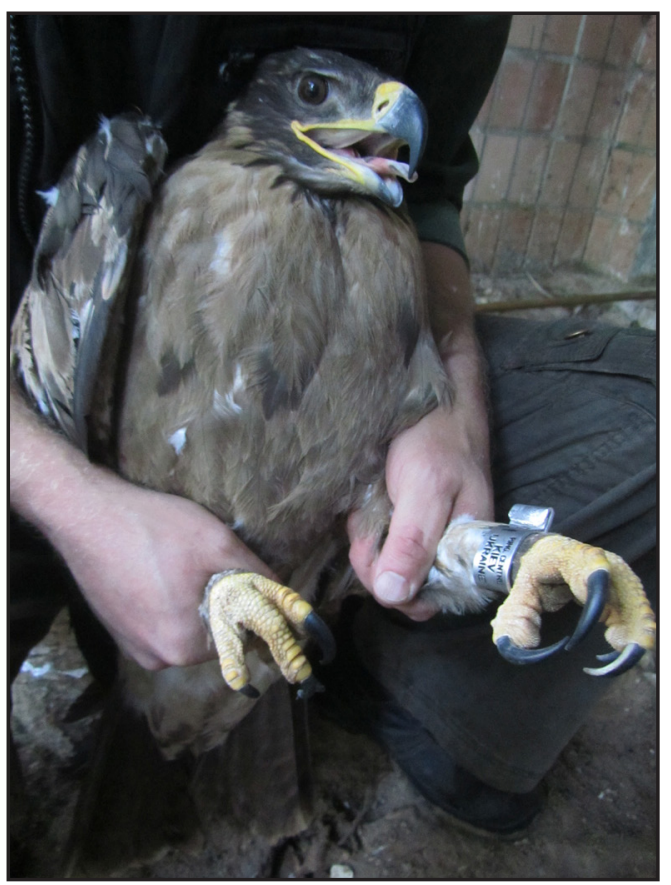

стае, но на помощь подоспели остамьные члены группы и началась борьба. Птица была несколько ослаблена, худая. Никаких внешних следов поврежлений не обнаружено, Аинька проходила без откионений от нормы. Симптомы инфекционных заболеваний также отсутствовами. После реабимитации (усиленное питание) 10.09.2016 г. птицу выпустили в степной балке на границе Первомайского и Змиевского районов (описание территории см. в п. 4). Птица хорошо летает. Вес в момент выпуска на волю составил 3,8 кг, обшая миина 71 см, миина крыла 54 см, миина киюва (от основания) 48 мм. Птицу снабдили кольцом серии РО номер 171 Украинского центра кольцевания.

Степной орёл в условиях региона является, пожалуй, наиболее уязвимым к разным вызовам природного и антропогенного характера, например, птицеопасным ^ЭП, транспорту, Аесициту кормов, отстрелу. Такой вывод можно слелать на основании Аанных о поступлении погибших крупных орлов в музей природы Харьковского национального университета, а также живых птиц в Харьковский зоопарк за период с 1993 г. по 2016 г. Так, при численности орла-могильника в Харьковской области приблизительно в 60-65 пар (всего не менее 120 взрослых особей и не менее 60 слетков ежкегодно) за указанный период времени в Харьковский зоопарк и Музей природы ХНУ Аоставлено 2 погибших и 4 живых орла. Беркут (Aquila chrysaetos) отмечен нами ежегонно на зимовках в количестве от 2-3 ях - около 10 особей в сезон, единичны случаи летовок; за указанный период нами установлена гибель 3 птиц. Численность орлана-белохвоста (Haliaeetus albicilla) в регионе оценена в 28-30 пар (около 60 взрослых особей и не менее 40 слётков ежегодно), за указанный период в зоопарк доставлено 2 птицы, в музей природы - 2 (одна из них погибла от энтерита), известно о гибели ешё 2 птиц. Интересно, что при наличии гнезАяшихся и летуюших особей подорликов (Ао 8 участков малого $A$. pomarina и 3 участка большого A. clanga), а также наиичии сушественного потока мигрантов этих видов (Аесятки особей в $\Delta$ мине Северского Аонца в один сезон миграции), за указанный период времени нам не известно ни одного случая поимки или отстрела этих птиц. В то же время 1 регистрация степного орла из 5 достоверных за этот же период относится к птице, которая была поймана и доставлена в зоопарк.

Распределение регистраций степного орла по временным диапазонам неравномерно: на 2 посленние года (2015-2016) приходится 3 из 5 регистраций степных орлов (весь период наблюдений охватывает 14 сезонов).

Степной орёл является глобально угрожаемым видом, и согласно новой оценке МСОП в Европейском Красном Аисте числится под категорией "CR» - «вид, находяшийся в критическом состоянии" (Карякин, 2015). Ближайшие к Харьковской области места гнездования степного орла расположены в Волгограцской области и в Каммыкии (Карякин, 2012). Каммыцкая "популяция", ранее одна из самых стабильных и многочисленных, демонстрируюшая высокую ахаптивную способность к изменяюшимся условиям гнездовых биотопов, например - ахаптация к гнездованию на низкорослых деревьях и опорах ^ЭП (Карякин, 2008), в настояшее время пребывает в не лучшей ситуации, главным образом из-за массовой гибели птиц и ухудшения показателей успешности гнездования, вызванного угасанием кормовой базы в Прикаспийских полупустынях и сухих степях (Карякин, 2012; см. также статью на стр. 61 в настояшем сборнике). В последние годы её численность оценивалась в Аиапазоне от 300-350 до 500-700 пар (Меджилов и мр., 2011; Музаев, ЭрАенов, 2013). В свете выше изложенных фактов вызывают удивление участившиеся случаи регистрации полувзрослых птиц на Аостаточно сушественном удалении от современных мест обитания вида. Откуда же берутся птицы мия расселения и дальних 
Степной орёл, Аоставленный в

Харьковский зоопарк в июне 2016 года во время возврашения в природу 10.09.2016. Фото С. Витера.

Steppe Eagle which was brought to the Kharkiv Zoo in June 2016 at the time of its releasing in the wild on 10 September 2016. Photo by S. Viter. путешествий, если запанные популяции степного орла находятся на пути к угасанию, не производя достаточного количества молодых? На наш взгляд есть два возможных объяснения.

Первый вариант - в запацных популяциях Аостаточно высока выживаемость молодых и взрослых птиц, что даже в условиях сокрашения количественных показателей репродукции позволяет сохраняться пулу полувзрослых птиц, наиболее склонных к Аамьним путешествиям; увеличение численности сусликов на востоке и северовостоке Украины делает этот регион привлекательным мля таких птиц.

Второй вариант - широкие перемешения за пределы традиционного ареала гнездовой группировки вовсе не означают её благополучие и могут не быть привязанными к позитивным показателям попумяционного тренда, а даже наоборот косвенно могут свидетельствовать о начале Аеструкции ялра Аанной гнезАовой группировки. Подобная ситуация имела место быть в начале 1970-х гг. в популяции туранского тигра (Panthera tigris virgata), когла после миительного отсутствия в республиках Средней Азии стали регулярно отмечать заходы одиночных самцов. Многими специалистами такая ситуация была воспринята как признак положительной Аинамики численности и расселения вила, но на самом деле это был последний «предсмертный всплеск" угасаюшей популяции, когла немногие уцелевшие звери пытались найти новые, более подходящие территории и широко кочевали по просторам Турана (Царук, Чикин, 2011).

Каковы перспективы возврата степного орла в состав гнездовой фауны Украины

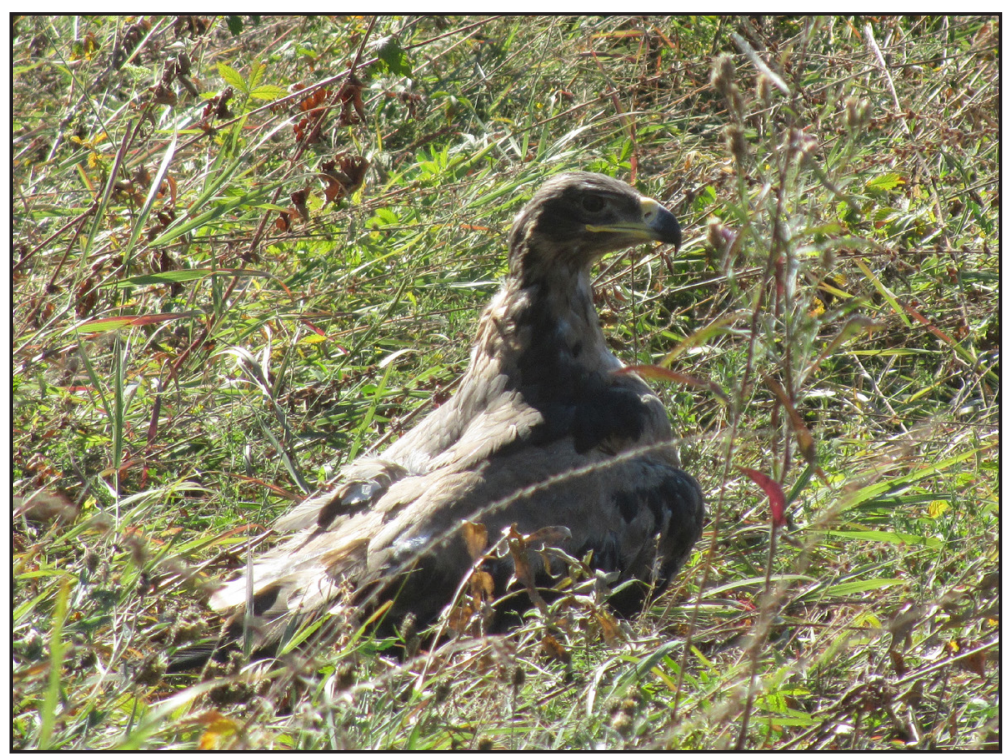

или хотя бы в качестве регулярно летуюшего виАа?

В настояшее время в Харьковской области происходит небольшое увеличение численности крапчатого суслика, пастбишная нагрузка достигла умеренных показателей, что способствует поцАержанию местообитаний сусликов и не достигает критического уровня перевыпаса. Существуют большие массивы степей, как по балкам на водоразделах, так и на террасах Северского Аонца (военные полигоны). Одновременно наметилась устойчивая тенденция к освоению старых залежей, появляются небольшие посацки лесных культур на скионах балок (правда, масштабы облесения степей в Харыковской области далеки от таковых в Аругих регионах страны). Сложная военно-политическая ситуация на востоке Украины, с одной стороны, привела к уменьшению пресса охоты в присронтовых регионах (прежле всего в Харьковской области, гле в 2014-2015 гг. вообше была закрыта охота), однако заметно возрос пресс на степные участки военных полигонов. Специальных мер по дератизации не проводят, а масштабы внесения пестицидов и инсектициАов в сельском и лесном хозяйстве далеки от таковых в пределах основного региона обитания вида - в России и Казахстане, не говоря уже о периоде СССР 1950-х - 1970-х гг. В то же время мия восточных регионов Украины актуальна проблема степных пожаров, иначе говоря умышленных поджогов сухой травянистой растительности: 2015 гол стал беспрецедентным, в Харыковской области выгорело более 80 \% степных участков. Стоит отметить, что в послеАние годы (2013-2016) степные пожары происходят в подавляюшем большинстве случаев осенью, что не влечёт к гибели гнёзд наземно-гнездящихся птиц, как при сушественных весенних палах до 2013 гола (особенно весной 2006 и 2007 гг.). Тем не менее, в результате выгорания травы и кустарников, происходит ухудшение зашитных свойств биотопа многим птицам попросту негле спрятать гнездо в низкой молодой весенней траве. Аостаточно серьезным ограничением может быть наличие гнездовой группировки орла-могильника, который также предпочитает степные и лесостепные ландшафть с колониями грызунов. Плюсом региона является отсутствие крупной гнездовой популяции фрилина (как, например, в степях Ауганской области Украины или Ростовской области РФ) - потенциального хиш- 
ника, способного добывать слётков и оказывать Аавление фактором беспокойства гнездяшейся пары орлов. В целом же нам видится маловероятным появление степного орла на гнездовании в Харьковской области в течение ближайших 10 лет, хотя искиючить таких отдельных случаев мы не можем. ОАновременно этот виц может перейти в разрял регулярно залётных в период миграций и регулярно встречаюшийся в гнезАовой сезон, но не размножаюшийся. Статус степного орла в настояшее время в Харьковской области: редкий, нерегулярно залётный в период миграций.

\section{Благодарности}

Автор выражает искреннюю благодарность начальнику отлела содержания хишных птиц Харьковского зоологического парка Влачимиру Ивановичу Гуку за предоставленные данные о крупных видах хишных птиц, Аоставленных из природы в Харьковский зоопарк за период с 1993 по 2016 гг. Также выражаем искреннюю благодарность главному смотрителю зоологической комекции Музея природы Харьковского национального университета (ХНУ им. В.Н. Каразина) Татьяне Николаевне $\triangle$ евятко за предоставленную инсормацию о крупных видах хишных птиц, $\Delta$ оставленных из природы в музей за период с 1993 по 2016 гг. Выражаем искреннюю благодарность Игорю Вячеславовичу Карякину за помощь в определении возраста степных орлов.

\section{Митература}

Витер С.Г. О статусе пребывания и особенностях биологии орлов в Харьковской области, Украина. - Пернатые хищники и их охрана. 2013. № 27. C. 102-121. [Virter S.G. On the Status of Stay and the Biology of Eagles in the Kharkov District, Ukraine - Raptors Conservation. 2013. 27: 102-121]. URL: http://rrrcn.ru/ru/ archives/21149 Аата обрашения: 20.09.2016.

Карякин И.В. Проблема "птицы и АЭП": есть и положительный аспект. - Пернатые хишники и их охрана. 2008. № 12. С. 11-27. [Karyakin I.V. Problem "Birds and Power Lines": Some Positive Effects Exist. - Raptors Conservation. 2008. 12: 11-27.]. URL: http://rrrcn.ru/ru/archives/24950 Аата обрашения: 20.09.2016.

Карякин И.В. Методические рекомендации по организации мониторинга популяций степного орла в России и Казахстане. Новосибирск, 2012. 89 c. [Karyakin I.V. Methods on the organization of monitoring of the Steppe Eagle populations in Russia and Kazakhstan. Novosibirsk, 2012: 1-89. (in Russian)]. URL: http://rrrcn.ru/ru/ archives/12822 Аата обрашения: 20.09.2016.

Карякин И.В. Повышен природоохранный статус степного орла. - Пернатые хищники и их охрана. 2015. № 30. С. 21-30. DOI: 10.19074/1814-8654-2015-30-21-30 [Karyakin I.V. The Steppe Eagle Global Conservation Status Was Raised. - Raptors Conservation. 2015. 30: 21-30. DOI: 10.19074/1814-86542015-30-21-30]. URL: http://rrrcn.ru/ru/archives/25956 Аата обрашения: 20.09.2016.

Кошелев А.И., Корзюков А.И., Аобков Е.Г., Пересацько А.В. Состояние численности редких и исчезаюших видов птиц. - Редкие птицы Причерноморья. Киев-ОАесса, 1991. С. 9-36. [Koshelev A.I., Korzyukov A.I., Lobkov E.G., Peresad'ko L.V. Population numbers of rare and endangered species of birds. - Rare birds of the Black Sea region. Kiev-Odessa, 1991: 9-36. (in Russian)].

Меджидов Р.А., Музаев В.М., Бацмаев В.Б. О состоянии популяции степного орла в Каимыкии. - Степной бюметень. 2011. № 32. С. 33-37. [Medzhidov R.A., Muzaev V.M., Badmaev V.B. On the state of the Steppe Eagle population in Kalmykia. - Steppe Bulletin. 2011. 32: 33-37.]. URL: http://savesteppe.org/ru/archives/6215 Аата обрашения: 20.09.2016.

Музаев В.М., Эрдненов Г.И. Материалы по численности и биологии размножения степного орла (Aquila nipalensis) на северо-востоке Калмыкии. - Орлы Палеарктики: изучение и охрана - тезисы международной научно-практической конференции, Елабуга (Татарстан, Россия), 2023 сентября 2013 г. / реА. А.А. Каюмов, И.В. Карякин, Э.Г. Николенко, Е.П. Шнайдер. - Елабуга, 2013. C. 40. [Muzaev V.M., Erdnenov G.I. Materials on the Numbers and Breeding Biology of the Steppe Eagle Aquila nipalensis in the NorthEast of Kalmykia. - Eagles of Palearctic: Study and Conservation - Abstracts of the International Scientific and Practical Conference, Elabuga, Tatarstan Republic, Russia, 20-23 September 2013 / Eds. A.A. Kayumov, I.V. Karyakin, E.G. Nikolenko, E.P. Shnayder. Elabuga, 2013: 40]. URL: http:// rrrcn.ru/ru/archives/19978 Аата обрашения: 20.09.2016.

Сомов Н.Н. Орнитологическая фауна Харьковской губернии. Харьков, 1897. 680 с. [Somov N.N. Ornithological Fauna of the Kharkov Region. Kharkov, 1897: 1-680. (in Russian)].

Царук О.И., Чикин Ю.А. Туранский тигр анализ современной ситуации. Москва, 2011. 37 c. [Tsaruk O.I., Chikin Yu.A. Turan tiger Analysis of the current situation. Moscow, 2011: 1-37.]. URL: http://www.wwf.ru/data/asia/ tiger/obzornye_materialy_k_otqetu_po_tigruuzbruss.pdf Аата обрашения: 20.09.2016.

Червона книга України. Тваринний світ. Київ: Укр. енцики., 1994. 457 с. [Red Data Book of Ukraine. Animals. Kiev, 1994: 1-457. (in Ukrainian)].

Червона книга України. Тваринний світ/ за ред. І.А. Акімова. Київ: Глобалконсаитинг, 2009. 600 c. [Red Data Book of Ukraine. Animals / ed. I.A. Akimov. Kiev, 2009: 1-600. (in Ukrainian)]. URL: http://redbook-ua.org/files/Red_book_animals_2009.zip Аата обрашения: 20.09.2016. 